\title{
MORPHOLOGICAL CHARACTERISTIC OF SPERMATOGONIA AND TESTES DISSOCIATION : A Preliminary Study for the Germ Cell Transplantation in Giant Gouramy (Osphronemus gouramy)
}

\author{
Irma Andriani ${ }^{* *}$, Ita Djuwita ${ }^{* *}$, Komar Sumantadinata**), M. Zairin Jr. ${ }^{\left.*{ }^{* * *}\right)}$, \\ Harton Arfah" ${ }^{* * * *}$, and Alimuddin ${ }^{* * * *}$ \\ *Department of Aquaculture, PhD student, Bogor Agricultural University \\ "*) Faculty of Animal Veterinary, Bogor Agricultural University \\ ***) Faculty of Fisheries and Marine Science, Bogor Agricultural University
}

(Received 23 August 2010; Accepted 6 December 2010)

\begin{abstract}
The recent study were attempting to develop spermatogonial germ cell transplantation as a tool to preserve and propagate male germ-plasm from endangered fish species, as well as to produce surrogate broodstock of commercially valuable fish. Spermatogonia identification and testes dissociation were the first necessary steps to obtain highly amount and viable population of spermatogonia as donor cells for transplantation. Using giant gouramy testes as a model, spermatogonia was histological characterized and two methods of testes dissociations were compared (i.e. medium A contained $0.5 \%$ trypsin in PBS and medium B contained $0.5 \%$ trypsin and DNase $10 \mathrm{IU} / \mu \mathrm{L}$ in PBS complemented with $\mathrm{CaCl}_{2}$, Hepes and FCS). Optimal incubation times (1, 2, 3, 4 and 5 hours) in dissociation medium were also determined. Freshly isolated testes of immature giant gouramy were minced in dissociation medium and then incubated to get monodisperce cell suspension. Parameters observed were number and viability of spermatogonia $(\varnothing>10 \mu \mathrm{m})$. The viability was analyzed using trypan blue exclusion dye. The results showed that the average number of spermatogonia observed in medium $B$ was higher than in medium $A(P<0.05)$, meanwhile the viability of spermatogonia between medium $A$ and $B$ were not significantly different $(P>0.05)$. The viability of spermatogonia decreased by the increasing duration time of dissociation. The viability of spermatogonia started to decrease significantly in 2 hours incubation time in medium $A$ and 4 hours incubation time in medium $B(P<0.05)$. In conclusion, application of dissociation medium $B$ yielded higher number of viable spermatogonia than dissociation medium $\mathrm{A}$.
\end{abstract}

KEYWORDS : testes, spermatogonia, morphology, dissociation, viability, giant gouramy

\section{INTRODUCTION}

Giant gouramy (Osphronemus gouramy) is an important, high valuable freshwater fish in Indonesia. However, giant gouramy is known to have slow growth rate and it reach sexual maturity in more than 2 years for male and 4-5 years for female. Consequently, farmer requires years to prepare full-cycle cultivation

\# Corresponding author. Department of Biology, Faculty of Math \& Science, Hasanuddin University, Jl. Perintis Kemerdekaan, Tamalanrae, Makassar, South Sulawesi, Indonesia. Tel.: + 6281281826130 E-mail address: andrianiirma@yahoo.com 
to produce juveniles. Therefore, the need to develop a new system is necessary to ensure sustainability of seed production in giant gouramy aquaculture.

Surrogate broodstock which is produced from germ cell transplantation technology may eventually be one of the alternatives in facilitating the production of commercially valuable fish with long generation time. This technology was applied successfully to some fish species resulted in donor-derived spermatogenesis in tilapia (Lacerda et al., 2008) and in gametes production by the recipient animal in salmonids (Takeuchi et al., 2004; Okutsu et al., 2006). Male germ cell contains spermatogonia, the only cell responsible for generating offspring (Brinster \& Avarbock, 1994). Male germ cell (as the donor cell) transplanted using microinjection technique into the peritoneal cavity of newly hatched embryo will migrate toward and form colony in the genital ridge of the recipient. Furthermore, donor-derived germ cell proliferated and differentiated into mature gametes in the recipient. If spermatogonia of giant gouramy were successfully transplanted into short generation time fish then gametes of giant gouramy could be easily and rapidly be produced. Therefore, germ cell transplantation technique does have the potential as a breakthrough technique to ensure sustainable seed production in giant gouramy culture.

Some basic techniques are required to be established for successful application of male germ cell transplantation in giant gouramy including the preparation of male germ cell enriched in spermatogonial cell population. To make the technique effective for transplantation, preparation of single germ cell suspension from a solid tissue is of critical importance. In general, it is important to maximize the number of viable cell, disperse clump of cells and minimize the reaggregation (Freshney, 2005). There are six variable conditions should be well defined to get suitable results, those are dissociation medium, type of enzyme(s), impurities in any crude enzyme preparation, concentrations of enzymes, temperature and incubation times (Worthington, 2003).

Various enzymatic dissociations had been introduced especially in high vertebrates, but poorly explained in fish. However, protocols for the preparation of male germ cells are species-specific because each species has its own anatomical characteristics, such as the relative amounts of connective tissue between tubules, lobulation, and the ease of removing the tunica (Kim et al., 2006). For these reasons, two dissociation methods were compared, first, it was referred to dissociation method in rainbow trout (Takeuchi et al., 2002) which used only one enzyme, that is trypsin and the second, it was referred to dissociation method in nibe croaker which used two enzymes, trypsin and DNase (Takeuchi et al., 2009). Trypsin is the strongest digestive enzyme and DNase is the weakest digestive enzyme (Worthington, 2009). Trypsin was used to deplete the extracellular matrix of glycoproteins and the subsequent rates of digestion of the residual matrix (Jones \& Werb, 1980). Meanwhile, DNase in some cases was added into the incubation media to prevent clotting of the resulting cell suspension due to the release of free DNA from dead cells (Crabbe et al, 1997). DNase hydrolyzed double-stranded DNA predominantly by a single-stranded nicking mechanism under physiological conditions when both $\mathrm{Ca}^{2+}$ and $\mathrm{Mg}^{2+}$ ions are present (Dwyer et al., 1999). This combination of enzymes perhaps could yield higher number of viable spermatogonia during dissociation.

Since the enzymes could cause detrimental effect to the cell as reported in some literatures (Nicosia et al., 1975; Bellve et al., 1977; Du et al., 2006) then the dissociation procedure should be arranged carefully including how long the cells should be exposed to the enzymes. Therefore, in this research the period of incubation time to determine the optimal incubation time that yield high number and viable spermatogonia was examined. Previously, morphological analysis for male germ cell types in giant gouramy was performed as a criteria in identification of giant gouramy spermatogonia germ cells.

\section{MATERIALS AND METHODS}

\section{Collection of Testes}

Testes were collected from immature giant gouramy (700-900 gram body weight) obtained from the Freshwater Aquaculture Development Centre in Sukabumi. Testes tissues for histologycal analysis $(n=4)$ were fixed immediately after collection. For the dissociation of germ cell, collected testes were washed twice with Phosphate Buffer Saline (PBS) pH=8.2 (Gibco). All connective tissue at posterior and anterior ends, blood capillary and fat attached to the 
gonad were removed from the collected testes and then the testes were cut into pieces of 20-30 mg each for dissociation analysis.

\section{Germ Cell Morphological Analysis}

Four testes samples were fixed in Bouin fixative for 24 hours, dehydrated along an ascending series of ethanol according to Kiernan method (1990), embedded in paraffin, and sectioned ( $5 \mu \mathrm{m}$ thickness). The block of tissue were sliced serially, and to avoid counting the same cell twice, 6 sections of $5 \mu \mathrm{m}$ thickness per fish were taken every $35 \mu \mathrm{m}$ sections. The sections were stained with Hematoxilin-Eosin for microscopic observation under a light microscope. Photographs were taken with an automatic Nikon camera. Germ cell type identification was referred to Takashima-Hibiya (1995). For measurement of diameter and morphological characterization of germ cell type, three fields of view per section were selected at random from the middle portion of the testis as much as 30 germ cells for each type. Additionally, six cysts per type of spermatogonia were analyzed to obtain the average number of each type of spermatogonia per cyst.

\section{Dissociation of Germ Cell}

Testes samples from 10 giant gouramy were used for tissue dissociation. Testes were minced with scissors and incubated in dissociation medium at room temperature. For the purpose of defining the effect of dissociation medium against the number and viability of spermatogonia germ cell, the testes were incubated in two different dissociation media:

a. Dissociation medium A : PBS (Gibco) containing $0.5 \%$ trypsin (Worthington), modified from Takeuchi et al. (2002).

b. Dissociation medium B : PBS (Gibco) containing $0.5 \%$ trypsin and $30 \mu \mathrm{l}$ of $10 \mathrm{IU} / \mu \mathrm{l}$ DNase (Sigma) in $1 \mathrm{ml}$ PBS supplemented with fetal bovine serum (Sigma), $\mathrm{Ca}^{2+}(1 \mathrm{mM})$ and 25 mM HEPES (Sigma), modified from Lacerda et al. (2008) and Takeuchi et al. (2009).

To obtain optimal incubation time yielded higher number of viable cell, five incubation times were examined, those were 1, 2, 3, 4 and 5 hours. During incubation, gentle pipetting was applied every 30 minutes to physically disperse any remaining intact portions of the testes. Then, the cell suspension was filtered through a $35 \mu \mathrm{m}$ pore-size nylon screen to eliminate non-dissociated cell clumps and washed twice with PBS. The number and viability of spermatogonial cells were analyzed using CX 10 microscope and haemocytometer. Viability of the cells was determined by the trypan blue dye exclusion test $(1: 1)$. Blue cell indicated damaged or death cell, while viable cell was transparent.

\section{Statistical Analysis}

Characterization of germ cell morphology $(n=100)$ was presented descriptively. Parameters for testes dissociation $(n=3)(n=$ number of trial) i.e. number and viability of spermatogonia were presented as mean. All statistical data analyses were performed using SPSS 17.0 statistical programm software. The statistical analysis was conducted using ANOVA. Differences among treatments were determined using Duncan multiple range test. The level of significance was set at $\mathrm{P}<0.05$.

\section{RESULTS AND DISCUSSION}

\section{Morphological Characteristic of Giant Gouramy Male Germ Cell}

The testes of giant gouramy constituted a short and relatively wide, bilobed organ, with the right lobe slightly shorter (Figure 1A). Cross section of seminiferous tubules at the middle part of giant gouramy testes was depicted in Figure 1B. Histological analysis showed that all testes examined were containing germ cell at all the stages of development. Like most of Perciformes, testes of giant gouramy were unrestricted spermatogonia in which spermatogonia were distributed along the lengths of giant gouramy testis tubules (Figure 1B).

Morphological characterization of gouramy's germ cells were determined based on several criteria such as cell and nuclear size, nuclear morphology, topological organization of germ cell and cell number per cyst (Figure 2A and 2B). Germ cell staging identified in giant gouramy was as follows : Primary A spermatogonium (spermatogonial stem cell), A spermatogonium (SpA), transitional spermatogonium $(\mathrm{SpT})$, B spermatogonium (SpB), primary spermatocyte, secondary spermatocyte, spermatid and spermatozoon. All proliferation stages between late A spermatogonia and early B spermatogonia were categorized as transitional spermatogonia. Thus, these morphological 


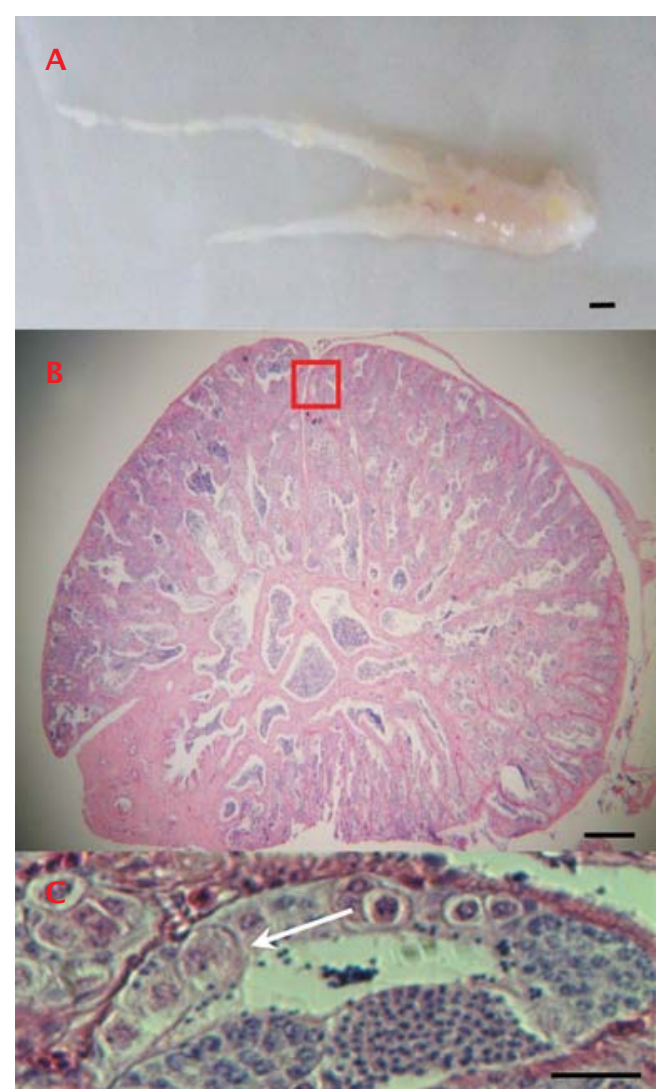

Figure 1. A. Testes, B. Cross section of testes of giant gouramy. Red box indicated section of testes that magnified in figure C. Bar $200 \mu \mathrm{m}$, C. Spermatogonia (arrow) were distributed closed to the lumina of testes tubule, HE. Bar $20 \mu \mathrm{m}$

analyses allowed us to determine that there were four types of spermatogonia in an immature giant gouramy weighed of 700-900 gram.

Spermatogonial stem cells (Figure 2B) were the largest single spermatogonia with a cytoplasmic diameter of $18.63 \pm 1.92 \mu \mathrm{m}$ and a nuclear diameter of $8.79 \pm 1.16 \mu \mathrm{m}$, and were mostly located close to the basement membrane of the germinal epithelium (Figure 1C). The nuclear membrane had an irregular outline, some of which remained unclear membrane as well. On the other hand, Sp A were smaller in size with a cytoplasmic and nuclear diameter of $15.96 \pm 1.53 \mu \mathrm{m}$ and $8.38 \pm 1.32 \mu \mathrm{m}$ respectively. They were surrounded by Ser- toli cells (Figure 2B), forming 2-4 germ cell in a cyst located close to the lumina of the tubules. Morphologically, SSC and some of SpA were ellipsoid.

There were some types of spermatogonia between A spermatogonia and B spermatogonia stage observed through all serial sections (Figure 2A). Since their nuclear morphology was very similar in varying diameters of germ cell, these types of germ cells were classified as transitional spermatogonia (SpT). Transitional spermatogonia were also located close to the lumina tubulus and forming 6-22 germ cells per cyst with a cytoplasmic and nuclear diameter of $12.33 \pm 1.17 \mu \mathrm{m}$ and $8.33 \pm 1.06 \mu \mathrm{m}$ respectively. The type $B$ spermatogonia were smaller than A spermatogonia with a cytoplasmic diameter of $8.88 \pm 1.41 \mu \mathrm{m}$ and a nuclear diameter of $5.83 \pm 0.95 \mu \mathrm{m}$. The number of $\mathrm{SpB}$ inside the cyst was 18-48 germ cells.

\section{Effect of Dissociation Medium on the Number and Viability of Spermatogonia}

Two dissociation media that were used for the isolation of giant gouramy male germ cell to determine which medium yielded the highest number of spermatogonia immediately after dissociation were examined. All of the protocols were performed in room temperature condition. In this case, we classified spermatogonia by morphological approach (diameter of cell) as being described previously. Spermatogonia was defined as a germ cell with diameter more than $10 \mu \mathrm{m}$. By trypan blue staining, a viable spermatogonia remained transparant color (Figure 3A) while a death spermatogonia or death cells had blue color (Figure 3B). The nuclei of spermatogonia germ cell was not clear performed natively, however some large germ cell were found showing transparent membrane and predicted as spermatogonial stem cell as showed in Figure 3C.

The result of testes dissociation showed that the average number of spermatogonia increased regarding to the increasing of incubation time. Dissociation medium B yielded higher average number of spermatogonia within the sequential incubation time compared to medium $A(P<0.05)$ (Table 1$)$. The viability of spermatogonia dissociated in medium $A$ and $B$ did not differ significantly $(P>0.05)$; however within certain sequential incubation time, the viability of spermatogonia showed significant dif- 


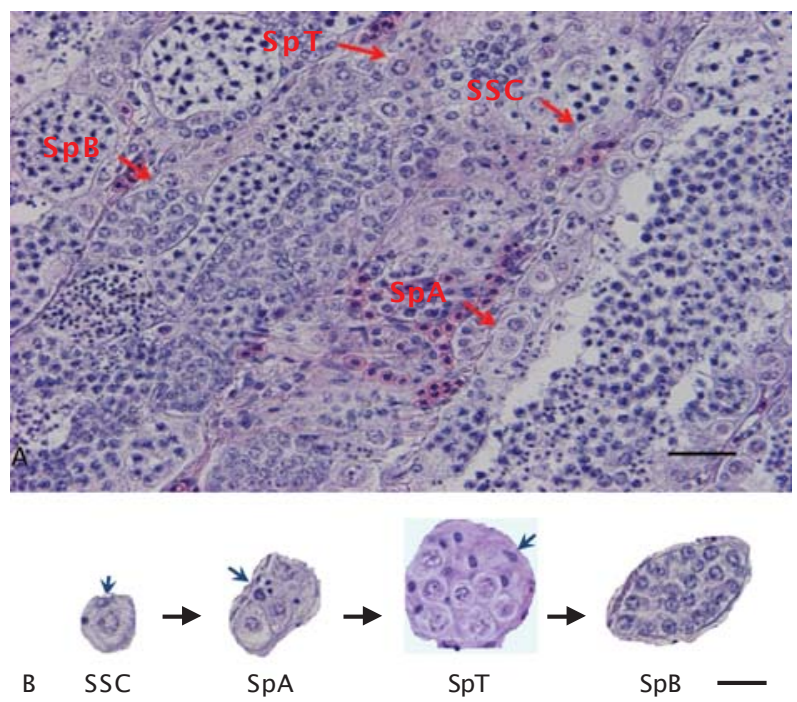

Figure 2. A. Cross section of giant gouramy testes (HE. Bar $50 \mu \mathrm{m}$ ). B. Cysts of spermatogonial types in giant gouramy, some enveloped by sertoli cells (red arrow): SSC $=$ spermatogonial stem cells, $\mathrm{SpA}=\mathrm{A}$ spermatogonia, $\mathrm{SpT}=$ transitional, $\mathrm{SpB}=\mathrm{B}$ Spermatogonia $(\mathrm{HE}$. Bar $20 \mu \mathrm{m})$

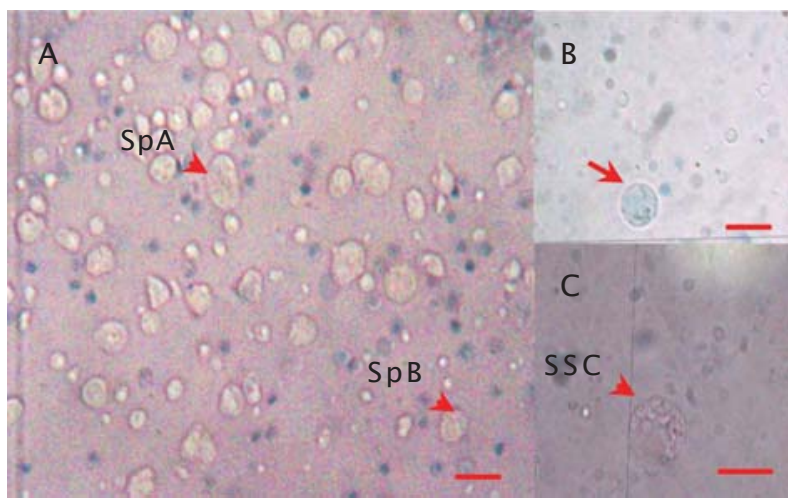

Figure 3. A. Male germ cell suspension of giant gouramy after dissociation. Black head arrow showing type viable spermatogonia. Bar $10 \mu \mathrm{m}$. B. Blue cells (white arrow) indicated death cells, Bar $10 \mu \mathrm{m}$. C. Stem cell spermatogonia was the largest diameter of cell and transparant membrane of cell. HE. Bar $20 \mu \mathrm{m}$

ferent referred to LSD post hoc test which will be discussed later. This phenomenon indicated that the composition of medium B encompassed two enzymes (trypsin and DNase) which supplemented with serum and $\mathrm{Ca}^{2+}$ to give better dissociation effect regarding to the high yield of spermatogonia during dissociation. Composition of dissociation medium B was modified from the dissociation medium used for nile tilapia (Lacerda et al., 2008) and nibe croacker (Takeuchi et al., 2009).

\section{Determination of Optimal Incubation Time in Dissociation Medium}

In this research, the optimal incubation times in each dissociation medium regarding 
Tabel 1. Number and viability of spermatogonia after dissociation in difference medium and sequential incubation time (mean \pm SEM, $n=3$ )

\begin{tabular}{|c|c|c|c|}
\hline Medium & $\begin{array}{l}\text { Incubation time } \\
\text { (hour) }\end{array}$ & $\begin{array}{c}\text { Number of spermatogonia/ } \\
\text { mg testes }\end{array}$ & Viability (\%) \\
\hline \multirow[t]{5}{*}{ A } & 1 & $15,946 \pm 3,475$ & $100.00^{a} \pm 0.00$ \\
\hline & 2 & $23,461 \pm 6,807$ & $98.15^{\mathrm{ab}} \pm 3.21$ \\
\hline & 3 & $29,429 \pm 15,390$ & $97.32^{\mathrm{ab}} \pm 2.52$ \\
\hline & 4 & $31,654 \pm 12,094$ & $95.20^{\mathrm{b}} \pm 0.94$ \\
\hline & 5 & $36,956 \pm 4,978$ & $94.15^{b} \pm 2.07$ \\
\hline \multirow[t]{5}{*}{ B } & 1 & $42,100 \pm 38,822$ & $100.00^{a} \pm 0.00$ \\
\hline & 2 & $53,316 \pm 33,713$ & $100.00^{a} \pm 0.00$ \\
\hline & 3 & $57,556 \pm 35,026$ & $97.51^{\mathrm{a}} \pm 0.93$ \\
\hline & 4 & $60,667 \pm 37,671$ & $96.00^{\mathrm{ab}} \pm 1.75$ \\
\hline & 5 & $62,952 \pm 17,757$ & $91.81^{b} \pm 5.84$ \\
\hline \multicolumn{4}{|c|}{ a, b : Superscript indicated the mean value differ significantly $(P<0.05)$} \\
\hline \multicolumn{4}{|c|}{ A : Medium composed with trypsin $0.5 \%$ in $1 \mathrm{~mL}$ PBS } \\
\hline \\
\hline
\end{tabular}

to the number and viability of spermatogonia yielded during incubating in sequencial time $(1,2,3,4$ and 5 hours) were also observed. The yield of dissociation (Table 1) showed the increasing number of spermatogonia as the increase of incubation time within some sequential incubation time. Regarding to the number of spermatogonia, the yield of dissociation differed significantly in 1 and 5 hours incubation time $(\mathrm{P}<0.05$; LSD post hoc test).

Moreover, the viability of spermatogonia showed significant difference within the sequential dissociation time in each medium $(P<0.05)$ (Table 1). In dissociation medium A, the viability of spermatogonia started to decrease in 2 hours of incubation. High significant decline of spermatogonia viability was observed in 4 hours of incubation. Meanwhile, in dissociation medium $B$, the viability of spermatogonia decreased significantly in 4 hours of incubation and even further in 5 hours of incubation. Therefore, we could determine based on the viability of spermatogonia that 1 hour was the optimal incubation time in dissociation medium $A$ and 3 hours was the optimal incubation time in dissociation medium $B$. Eventhough there was no detailed information about the cell viability and cell yield after dissociation in fish, most of teleost fish only take 2 hours for incubation in their dissociation pro- tocol such as rainbow trout (Okutsu et al., 2006), nile tilapia (Lacerda et al., 2008) and nibe croacker (Takeuchi et al., 2009). In giant gouramy, the viability of spermatogonia still could be maintained for 3 hours in dissociation medium $B$. Therefore the higher number of spermatogonia should be possibly produced during the incubation. These results indicated that dissociation medium $B$ gave a better condition for spermatogonia during incubation time than dissociation medium $A$.

\section{Discussion}

Spermatogonia are stem cells that can replenish their own population and simultaneously producing sperm on a renewable basis. This fact has become a benefit in technical application of assisted reproduction based on spermatogonia such as transplantation, cell culture or preservation of endangered and genetically valuable animals. This research is a first step prior to the effort to produce surrogate broodstock using giant gouramy as a donor and transplantation technique assay. One of major limitations to the transplant procedure is that the donor germ cell mixture contained an unknown number of spermatogonia (Griswold et al., 2001). This research had shown the morphological characteristics as well as the number and viability of sper- 
matogonia could be obtained in sequential incubation time.

To increase the efficiency of transplantation, the percentage of spermatogonia with stem characteristic (Undifferentiated spermatogonia including spermatogonia stem cell and A spermatogonia) should be increased (Shinohara \& Brinster, 2000). One of the first successful studies increased the relative number of spermatogonia colonized in recipient by using testicular cell that were selected based on the ability of the cell to interact with the basemembrane of the seminiferous tubules (Shinohara et al., 1999). In this research we just observed the type of testicular cells including type of spermatogonia morphologically using histological approach. Moreover, for viability assay, we used trypan blue vital staining to characterize the normal viable cells. Those technique approaches had major limited information, but they helped us to prepare mixed germ cell enriched with high number and viable spermatogonia for giant gouramy transplantation assays.

Prior to dissociation of testes, we studied the morphological structure of testes and male germ cell types in giant gouramy. Testicular parenchyma of giant gouramy show typical organization as most of fish with two major components; the tubular and intertubular compartments. Similar to vertebrate, the organization of testes in fish has been described clearly that the tubular compartment comprises of seminiferous epithelium, where the Sertoli/ germ cells units called cysts are located, the tunica propria compose of basal lamina and peritubular myoid cells, and the tubular lumen is filled with fluid secreted by Sertoli cells (Nóbrega et al., 2009). While the intertubular compartment containing Leydig cells, connective tissue cells, and blood vessels (Grier 1993; Pudney 1993; Nóbrega \& Quagio-Grassiotto 2007). The seminiferous tubules contain spermatogenic cysts, a group of synchronously developing germ cells that are enveloped by Sertoli cells, which are derived in a clonal manner from one stem cell or A spermatogonia in which interconnected by cytoplasmic bridge (Loir et al., 1995 ; Lacerda et al., 2008).

The morphological characteristic of germ cell types of giant gouramy was in general similar to most species of teleost fishes described by previous studies (Vilela et al., 2003; Schulz et al., 2005). With histological approach, mor- phological features of giant gouramy germ cell type based on nuclear diameter, cytoplasm diameter and the number of germ cell per cyste were analyzed. Only four generations of spermatogonia could be classified morphologically in this research as $5 \mu \mathrm{m}$ histological sections disable to describe the nuclear morphology in clear performance. However, between undifferentiated spermatogonia (stem cell spermatogonia and A spermatogonia) and differentiated spermatogonia (B spermatogonia) showed significant differences of cytoplasmic and nuclear diameter $(\mathrm{P}<0.05)$. A spermatogonia in giant gouramy were found at random sites along the seminiferous tubule throughout the testis. This type of germ cell organization has been classified as unrestricted type, a primitive character that appears to exist in a number of teleost fish orders such as cyprini formes, perciformes and others (Parenti \& Grier, 2004; Leal et al., 2009).

Since each species has its own anatomical characteristics such as the relative amount of connective tissue between tubules, lobulation, the ease of removing tunica, topological posistion of germ cell type need to be isolated then the protocol for the preparation of donor cell are species- specific (Kim et al., 2006). For these reasons, two protocols, those of modified protocol from Takeuchi et al (2002) and modified protocol from Lacerda et al. (2008) and Takeuchi et al. (2009) were compared, the latter of which proved to be more efficient for giant gouramy. However, before exposure to digestive enzymes, 2 mechanical steps were required: first, removal of testicular blood vessels to reduce contamination with blood cell, and the grossly visible connective tissue associated with the testes facilitated a more uniform digestion of the testicular parenchyma. Second, minced process of testes and gently pipetting of cell suspension provide an effective and fast enzimatic digestion. However, squeezing the testes or roughly pipetting should be avoided in order not to cause any damage. According to the observation, these mechanical steps caused high variation number of spermatogonia yielded that finally resulted unsignificant difference of the number of spermatogonia yielded within sequential incubation time from 1 to 5 hours according to the statistical analysis.

Exposuring mince of testes to dissociation medium B which comprised of two enzymes, trypsin and DNase, in fact yielded nearly 
double fold number of spermatogonia than that of one enzyme (medium A). It has been demonstrated that DNase treatment in dissociation of human erythrocyte released actin from cytoskeleton. DNase can then solubilize the structural actin and prevent actin polimerization (Sheetz, 1979). DNase will digest the released materials of death cells and then reduce the viscosity of the suspension (Helmrich \& Barnes, 1998). According to our experience during transplantation process, low viscosity of suspension plays an important role in the process of sucking the germ cell into the needle and then injecting the suspension into the target organ. Therefore, DNase is a crucial material for the transplantation technique since it is not only increasing the number of spermatogonia during dissociation but also able to keep germ cells as single cells and reduces viscosity of cell suspension. Another component of dissociation medium B such as $\mathrm{Ca}^{2+}$, Hepes, and serum also play an important role to maintain cells in good conditions. Hepes provides additional buffering capacity and stabilizes the $\mathrm{pH}$ during incubation in dissociation medium. Elements in the chemical environment of the cell such as heavy metals can also damage cells if they are not bound and sequestered (Mather \& Roberts, 1998). Serum with variety of proteins provides this protection in dissociation medium. Therefore, dissociation medium $B$ gave better condition for germ cells since the viability of spermatogonia in medium B could be maintained high (97.51\%) until 3 hours incubation.

Dissociation medium B yielded high number and viability of spermatogonia than dissociation medium A, but for economical reasons, the material components of dissociation medium A should be considered as they are cheaper and easier to get. This research has succesfully showed that both dissociation medium $A$ and dissociation medium $B$ could be applied for donor cell preparation of giant gouramy.

Higher number of spermatogonia obtained after dissociation will be resulted in higher numbers of recipients that could be injected. According to Okutsu et al. (2006), approximately 10,000 male germ cells were transplanted i.p. into newly hatched (32-35 days post fertilization) allogenic rainbow trout fry. The transplanted germ cells had incorporated into the genital ridges of $43 \%$ of the recipient fish 20 days post transplantation. If suitable recipient from related species with short generation time for giant gouramy cell donors could be found, then about 57.000 spermatogonia/mg testes obtained from 3 hours dissociation in medium B (assuming 10\% of total number of testicular cells) could be injected into about 57 recipient with $43 \%$ successful incorporation. Therefore, Each $1 \mathrm{mg}$ testes of giant gouramy could produce about 25 surrogate broodstocks. This calculated number is very promising for an alternative method to produce giant gouramy with short generation time.

\section{CONCLUSION}

The study demonstrated that dissociation medium in PBS containing trypsin and DNase suplemented with $\mathrm{CaCl}_{2}$, Hepes and serum (medium B) yielded high number and viability of spermatogonia than dissociation medium in PBS containing trypsin only. Therefore dissociation medium B were more recommended for germ cell preparation in spermatogonial transplantation assay for giant gouramy. Incubation time recommended for testes dissociation using medium B was less than 3 hours.

\section{ACKNOWLEDGEMENT}

The authors would like to thank Prof. Goro Yoshizaki of The Univesity of Marine Science and Technology (TUMSAT) Tokyo, Japan for his assitance during the Training of Dissociation and Transplantation at his laboratory as part of SANDWICH program (2008-2009) supported by the General Directorate of Higher Education, Indonesia. The authors would also like to thank the Freshwater Aquaculture Development Centre in Sukabumi for providing materials and support of giant gouramy dissociation.

\section{REFERENCES}

Bellve, A.R., Milletfe, C.F., Bhatnagar, Y.M., \& O'Brien, D.A. 1977. Dissociation of the mouse testis and characterization of isolated spermatogenic cells. The journal of Histochemistry and Cytochemistry, 25(7): 480-494.

Brinster, R.L. \& Avarbock, M.R. 1994. Germline transmission of donor haplotype following spermatogonial transplantation. Proc. Natl. Acad. Sci., 91: 11,303-11,307

Crabbe, E., Verheyen, G., Tournaye, H., \& Van Steirteghem, A. 1997. The use of enzymatic procedures to recover testicular 
germ cells. Human Reproduction, 12(8): 1,682-1,687.

Du, M., Han, H., Jiang, B., Zhao, L., Qian, C., Shen, H., Xu, Y., \& Li, Z. 2006. An efficient isolation method for domestic hen (Gallus domesticus) ovarian primary follicles. Journal of Reproduction and Development, 52(4): 570-576.

Dwyer, M.A., Huang, A.J., Pan, C.Q., \& Lazarus, R.A. 1999. Expression and characterization of a DNase I-Fc fusion enzyme. The Journal of Biological Chemistry, 274(14): 9,7389,743 .

Freshney, R.I. 2005. Culture of Animal Cells: a manual of basic technique ( $5^{\text {th }}$ edition). John Wiley and Sons Inc., 580 pp.

Grier, H.J. 1993. Comparative organization of sertoli cells including the sertoli cell barrier. In: Russell, L.D. \& Griswold, M.D. (eds). The Sertoli cell. Cache River Press., p. 704739.

Griswold, M.D., McLean, D., \& Russell, L. 2001. Promise and limitations of germ cell transplantation in the testis. Journal of Andrology, 22: 5.

Helmrich, A. \& Barnes, D. 1998. Animal cell culture equipment and techniques. In : Mather J.P. and D. Barnes (Eds). Animal Cell Culture Methods. Academic Press. USA, 57: 3-19.

Jones, P.A. \& Werb, Z. 1980. Degradation of connective tissue matrices by macrophages: Influence of matrix composition on proteolysis of glycoproteins, elastin, and collagen by macrophages in culture. J. Exp. MED, 152: 1,527-1,536.

Kiernan, J.A. 1990. Histological and Histochemical Methods: theory and practice. Pergamon Press, Toronto, 480 pp.

Kim, Y., Selvaraj, V., Dobrinski, I., Lee, H., Mcentee, M.C., \& Travis, A.J. 2006. Recipient preparation and mixed germ cell isolation for spermatogonial stem cell transplantation in domestic cats. Journal of Andrology, 27: 2.

Lacerda, S.M.S.N., Batlouni, S.R., Assis, L.H., Resende, F.M., Campos-Silva, S.M., CamposSilva, R., Segatelli, T.M., \& Franca, L.R. 2008. Germ cell transplantation in tilapia (Oreochromis niloticus). Cybium, 32(2): 115118.

Leal, M.C., Cardoso, E.R., Nóbrega, R.H., Batlouni, S.R., Bogerd, J., França, L.R., \& Schulza, R.W. 2009. Histological and stereological evaluation of zebrafish (Danio rerio) spermatogenesis with an emphasis on spermatogonial generations. Biology of Reproduction, 81(1): 177-187.

Loir, M., Sourdaine, P., Mendis-Handagama, S.M.L.C., \& Jégou, B. 1995. Cell-cell interactions in the testis of teleost and elasmobranchs. Micr. Res. Tech., 32:533-552.

Mather, J.P. \& Roberts, P.E. 1998. Introduction To Cell and Tissue Culture: theory and technique. Plenum Press. New York, 241 pp.

Nicosia, S.V., Evangelista, I., \& Batta, S.K. 1975. Rabbit ovarian follicles. I. isolation technique and characterization at different stage of development. Bioloogy Reproduction, 13: 423-447.

Nóbrega, R.H. \& Quagio-Grassiotto, I. 2007. Morphofunctional changes in Leydig cells throughout the continuous spermatogenesis of the freshwater teleost fish, Serrasalmus spilopleura (Characiformes, Characidae): an ultrastructural and enzyme study. Cell Tissue Res., 329(2): 339-349.

Nóbrega, R.H., Batlouni, S.R., \& Franca, L.R. 2009. An overview of functional and stereological evaluation of spermatogenesis and germ cell transplantation in fish. Fish Physiol Biochem., 35: 197-206.

Okutsu, T., Suzuki, K., Takeuchi, Y., Takeuchi T., \& Yoshizaki, G. 2006. Testicular germ cells can colonize sexually undifferentiated embryonic gonad and produce functional eggs in fish. Proc. Natl. Acad. Sci., 103(8): 2,725-2,729.

Parenti, L.R. and H.J. Grier. 2004. Evolution and phylogeny of gonad morphology in bony fishes. Integ. Comp. Biol., 44: 333-348.

Pudney, J. 1993. Comparative cytology of the non-mammalian vertebrate sertoli cell. In: Russell LD and Griswold MD (eds). The sertoli cell. Clearwater, FL. Cache River Press, $657 \mathrm{pp}$.

Schulz, R.W., Menting, S., Bogerd, J., Franca, L.R., Vilela, D.A.R., \& Godinho, H.P. 2005. Sertoli cell proliferation in the adult testis - evidence from two fish species belonging to different orders. Biology of Reproduction, 73: 891-898.

Sheetz, M.P. 1979. DNase I-dependet dissociation of erythrocyte cytoskeletons. J. Cell Biology, 81 : 266-270.

Shinohara, T., Avarbock, M.R., \& Brinster, L.R. 1999. Beta 1 - and alpha6-integrin are sur- 
face markers on mouse spermatogonial stem cells. Proc. Natl. Acad. Sci., 96:55045509.

Shinohara, T. \& Brinster, L.R. 2000. Enrichment and transplantation of spermatogonial stem cells. Int. J. Androl., 23: 89-91.

Takashima, F. \& Hibiya, F. 1995. An Atlas of Fish Histology: normal and pathological features, $195 \mathrm{pp}$.

Takeuchi, Y., Yoshizaki, G., Kobayashi, T., \& Takeuchi, T. 2002. Mass isolation of primordial germ cells from transgenic rainbow trout carrying the green fluorescent protein gene driven by the vasa gene promoter. Biology of Reproduction, 67: 1,087-1,092.
Takeuchi, Y., Takeuchi, T., \& Yoshizaki, G. 2004. Surrogate broodstock produces salmonids. Nature, 430: 630-639.

Takeuchi, Y., Higuchi, K., Yatabe, T., Miwa, M. \& Yoshizaki, G. 2009. Spermatogonial cell transplantation in marine teleost. Biology of Reproduction, 81(6): 1,055-1,063.

Vilela, D.A.R., Silva, S.G.B., Peixoto, M.T.D., Godinho, H.P., \& Franca, L.R. 2003. Spermatogenesis in teleost: insights from the Nile tilapia (Oreochromis niloticus) model. Fish Physiol Biochem., 28: 187-190.

Worthington. 2003. Tissue Dissociation Guide. Worthington Biochemical Corporation, 117 pp. 